\title{
Avsked i coronatider
}

\section{Att ta farväl av döende nära anhöriga $i$ tider av restriktioner}

\begin{abstract}
Farewell in corona times. To say good bye to dying next of kin in times of restrictions

In our society, great importance is attached to being able to say goodbye to loved ones when they are dying. The Covid-19 pandemic not only causes deaths but also creates barriers to being present in the dying process. In a study conducted in 2020, nine people whose next of kin died during Covid-19 restrictions were interviewed. The aim of the article is to make visible norms and ideas about final farewells and to identify how the interviewees handle their feelings when deviating from, or fulfilling, these norms. The most prominent ideals are for relatives to be physically and emotionally present at the deathbed, both to support the dying person and to better handle the grief. The interviewees who found ways to be present express pride and gratitude, while those unable to be present express anxiety, guilt, helplessness, and pain. To deal with their emotions they try to establish trust both in the necessity of the Covid-19 restrictions and in the staff that worked with their deceased relatives.
\end{abstract}

Keywords: Covid-19, restrictions, death, farewell, emotions

\section{Värdigt avsked under covid-19-pandemin?}

I vårt samhälle läggs stor vikt vid att vi ska kunna ta avsked av våra nära och kära när de ligger för döden. Att ta farväl anses vara viktigt för de anhörigas sorgeprocess och i den statliga offentliga utredningen Döden angår oss alla. Värdig vård vid livets slut framhålls att tid ska ges för ett "värdigt avsked" (Kommittén om vård i livets slutskede 2001:90). I Socialstyrelsens rapport Nationellt kunskapsstöd för god palliativ vård i livets slutskede (2013) nämns dessutom den döendes möjlighet till bevarande av sina sociala relationer som ett av flera viktiga element för en "god död" och i Döden angår oss alla slås fast att "ingen ska behöva dö ensam" (Kommittén om vård i livets slutskede 2001:60-61).

Pandemin covid-19 har inte bara orsakat ett stort antal dödsfall utan också skapat hinder för att besöka anhöriga och närvara i dödsprocessen, även när dödsorsaken inte är covid-19. I syfte att begränsa smittspridning av covid-19 införde många sjukhus och äldreboenden besöksförbud alternativt strikta regleringar av besök under våren 
2020 (Coronakommissionen 2020; SKR 2020). Även för dem som befann sig hemma uppkom nya hinder. I vår studie, som genomfördes under 2020, besvarar vi frågor om hur restriktioner i samband med covid-19 påverkade människors möjligheter och sätt att visa omsorg om samt ta farväl av döende nära anhöriga. Syftet med denna artikel är att synliggöra normer, det vill säga informella och ofta underförstådda sociala regler, och föreställningar kring avsked samt analysera hur de intervjuade hanterar sina känslor vid avsteg från respektive uppfyllande av dessa normer. Analysen baseras på nio djupintervjuer med personer som haft en eller flera anhöriga som avlidit under den tid då restriktioner kring fysisk kontakt gällt. Genom att studera avsked i en situation som avviker från den "normala" får vi syn på just det normala, det vill säga dominerande föreställningar och normer kring det ideala avskedet. Frågor vi diskuterar är: Vilka normer och föreställningar kring döende och avsked ger de intervjuade uttryck för? Vad framställs som ett idealt avsked och vad är det som anses viktigt? Vilka erfarenheter har de intervjuade av att ta farväl av sina döende nära anhöriga i samband med eventuella restriktioner på grund av covid-19? Vilka emotioner väcks av att i olika grad kunna och inte kunna leva upp till det ideala avskedet? Hur hanterar de nära anhöriga dessa erfarenheter och känslor?

Sveriges har, i likhet med flera andra europeiska länder, hanterat covid-19 med utgångspunkt i ett socialt kontrakt med förväntan om ömsesidig tillit mellan landets myndigheter och dess invånare (Kavaliunas, Ocaya, Mumper m.fl. 2020). Individen har fått ta ett stort ansvar för att följa de rekommendationer som Folkhälsomyndigheten utfärdat samt de lagar som Sveriges regering antagit. Till de mer tvingande restriktionerna som Sverige införde under våren 2020 hör förbudet mot besök på äldreboenden med fler än 50 boenden. Trots detta drabbades Sveriges äldreboenden av utbredd smittspridning och hög dödlighet (SKR 2020). Samtidigt lyckades man under 2020 att undvika en alltför stor överbelastning på sjuk- och intensivvården.

Döden både formas och erfars genom sociala relationer; mellan döende och anhöriga, döende och olika former av professionella grupper och också inom yrkesgrupper och mellan anhöriga som lämnats kvar. Vi som sociologer kan bidra med att situera dessa relationella processer i en samhällelig kontext. Vi kan synliggöra hur normer, policytexter, etiska riktlinjer och inte minst våra olika livsvillkor sätter ramar för hur vi kan erfara och forma döende och död. När fyra sociologer samtalade om coronakrisen i Sociologisk Forskning under våren 2020 uppmärksammades bland annat att frågor om ojämlikhet och makt var särskilt viktiga att belysa sociologiskt (Danielsson, Liljeros, Mulinari m.fl. 2020). I vår studie har vissa ojämlikhetsaspekter kunnat analyseras, men vi ser ett stort behov av vidare forskning om hur erfarenheter av avsked villkoras av ojämlikhet. Vår studie ger utrymme åt berättelser från anhöriga som inte enbart förlorat en nära, utan också förlorat möjligheten att ta farväl på ett sätt som känts tillräckligt. Därigenom hoppas vi kunna bidra till att göra deras erfarenheter och känslor begripliga och legitima i den ovanliga tid vi genomlevt och skapa bättre förståelse för människors behov i samband med avsked på ett mer generellt plan.

Texten är disponerad på följande vis: vi inleder med att beskriva teoretiska begrepp och tidigare forskning för att därefter diskutera våra metodologiska val. Analysdelen är 
indelad tematiskt och vi avslutar med att svara på våra frågeställningar, lyfta poänger samt föreslå vidare forskning.

\section{Att hantera döende och död: emotioner och interaktionsritualer}

Döende och död beforskades länge huvudsakligen inom medicin, psykologi och religionsvetenskap, men från 1950-talet och framåt kan vi se hur thanatosociologin, också kallad dödssociologin, vuxit fram. Michael Hviid Jacobsen (2010) menar att thanatosociologin i dag står inför nya utmaningar. En av de sex utmaningar som Jacobsen listar handlar om att vi som sociologer bör studera också de dödsfall som avviker från normen eller som är dramatiska på olika sätt. Vår studie tar sig an denna utmaning. Eftersom professionaliserings- och medikaliseringsprocesser har bidragit till ett främmandegörande av döden (se till exempel Elias 1985) möter vi döden mer sällan i vårt vardagsliv. Döden betraktas då $i$ sig som en anomali, ett tabu och en avvikelse från det önskvärda: liv, hälsa och evig ungdom (Hviid Jacobsen \& Brødslev Olsen 2014). I en senare text problematiseras dock denna bild när Hviid Jacobsen (2016) hävdar att vi lever i en tid av "spektakulär död", snarare än i en tid av tabu och hemlighållande av döden. Med spektakulär död åsyftar han hur vi bland annat på grund av media, kommersialisering och nya och gamla former av ritualisering befinner oss i en tid av förnyat intresse och fascination inför döden, döendet och förluster, speciellt när dessa sker under våldsamma former. Genom att på olika sätt synliggöras i det mediala rummet har döden i dag blivit mer påträngande och invaderande än den var för några decennier sedan.

En av de allra första sociologerna som specifikt intresserade sig för döden var Émile Durkheim som i slutet på 1800-talet studerade självmordet ur ett funktionalistiskt perspektiv (Durkheim 1983[1897]). Han pekade på samhällets behov av kollektiva ritualer som ett sätt att återskapa sammanhållning när kollektivet hade hotats eller erfarit en förlust, som till exempel vid dödsfall. Det är just denna typ av kollektiva ritualer som störs när restriktioner i samband med covid-19 hindrar människor från att samlas. Randall Collins (2005) fördjupar sig i den emotionella betydelsen av ritualer. Han menar att i stort sett alla typer av sociala interaktioner, i vilka minst två personer är fysiskt närvarande, har ett gemensamt fokus och bygger upp en gemensam känsla, kan benämnas interaktionsritualer. När en interaktionsritual lyckas genereras positiva känslor som till exempel solidaritet i gruppen och emotionell energi för den individuella deltagaren. Emotionell energi leder till att jaget bekräftas och kan ge ökat självförtroende, initiativförmåga och lust att göra sådant som gruppen betraktar som rätt och bra. Den existentiellt viktiga situation som döden är erbjuder en möjlighet till intensiv emotionell energi för dem som kan genomföra en lyckad interaktionsritual, något som vi menar hänger samman med de normer om gemenskap som finns kring döende, död och avsked. Interaktionsritualer är ett viktigt teoretiskt verktyg för oss i analysen av intervjumaterialet.

Emotioner är centrala för hur vi människor agerar och relaterar till oss själva och andra i världen. Det blir inte minst kännbart i dödens närhet då starka känslor väcks. 
Vilka emotioner som erfars och uttrycks formas också av normer kring vilka känslor som anses passande i olika situationer och positioner. I våra intervjuer blir det påtagligt hur intervjupersonerna utför det som Arlie Hochschild (1979) kallar emotionsarbete, det vill säga anstränger sig för att känna och ge uttryck för sina känslor på ett sätt som framstår som adekvat och begripligt också för andra. Detta emotionsarbete är interaktivt och kan vara både medvetet och omedvetet (Theodosius 2006). I vår analys blir empatiska föreställningar centrala både för emotioner och emotionshantering. Empati handlar om förmågan att föreställa sig någon annans känslor, där just föreställningar om är en viktig dimension eftersom det inte går att få tillgång till och säkert veta någon annans känslor (Morton 2013; Cuff, Brown, Taylor m.fl. 2016). Detta förstärks i relation till personer som är sjuka och döende, eftersom de ofta inte längre kan kommunicera fullt ut. Att inte få träffas, vara i samma rum och ta i varandra kan också skapa större utrymme för egna fantasier om den anhörigas känslor och behov. Dessa empatiska föreställningar väcker i sin tur känslor hos intervjupersonerna, som till exempel skuld eller oro (Morton 2013). Genom att styra sina föreställningar om sina anhörigas situation och känslor, kan intervjupersonerna också forma sina egna känslor. En känsla av betydelse i omsorgsrelationer är skuld (Björk 2018). Skuld orsakas av känslan av att ha svikit någon man känner ansvar för (Kemper 2007). I avskedet av nära anhöriga är omsorg, och ansvar att finnas närvarande för den döendes skull, viktiga dimensioner. Att inte kunna närvara kan innebära känslor av skuld. Men om den anhöriga inte själv kunnat välja närvaro och därmed inte känner ansvar för frånvaron kan skuld få mindre betydelse. I vår analys av hur intervjupersonerna hanterar ovisshet vid utebliven möjlighet att själv närvara, och ibland också utebliven information från vårdande personal, är tillit ett relevant begrepp. Tillit handlar enligt Jack Barbalet (2009) om att upprätta förtroende för den andra och för den egna förmågan att göra bedömningar av den andras pålitlighet i en asymmetrisk situation då vi inte har tillräckligt mycket information. Tillit öppnar för sårbarhet genom att vi väljer att ha tillit trots att vi vet att vi kan bli svikna och lurade, eftersom det hjälper oss att hantera vår osäkerhet och vårt beroende av andra och vi hoppas på ett resultat som utan tillit inte hade varit möjligt. Tilliten blir därmed ett verktyg för att hantera emotioner och utstå osäkerhet och sårbarhet genom att känna förtroende. När tilliten brister skapar det inte bara känslor av vrede mot andra, utan också självförebråelser för att man själv brustit i bedömningen av den andres pålitlighet.

Om vi själva lever ett långt liv är det oundvikligt att människor som står oss nära dör. Vi tar avsked av våra nära och kära i olika former och under olika villkor - även när pandemier inte härjar och sätter upp begränsningar för oss. Eftersom människor inte alltid kan ta farväl under ideala omständigheter har denna undersökning relevans bortom covid-19. Ett område där detta har studerats är migranters erfarenheter av att förlora nära anhöriga och hur de, på grund av avstånd, exil eller andra omständigheter, inte kan närvara vid dödsstunden - och heller inte tiden innan eller vid olika former av ritualer efter dödsfallet. Forskare lyfter hur detta kan skapa känslor av hjälplöshet, skuld, ilska och ånger samt hur det riskerar att komplicera sorgeprocessen för de efterlevande (Bravo 2017; Mas Giralt 2019; för en kvantitativ studie om hur uteblivet 
avsked komplicerar sorgeprocessen för människor generellt, se även Holland, Plant, Klingspon m.fl. 2020). I många studier uppmärksammas hur den digitala tekniken fungerar överbryggande för migranter i upprätthållandet av kontakt och relationsskapande med familj och vänner de lämnat när de migrerade - även om det inte anses kunna ersätta fysisk närhet och interaktion ansikte mot ansikte (Baldassar 2008; Osteruk 2018; Mas Giralt 2019).

Andra exempel på död under onormala omständigheter är död i samband med krig, ebola samt hiv och aids. Vi ser vår studie som en del av dessa forskningsfält, men i denna artikel begränsar vi oss till att hämta inspiration från ett par studier om ebola. När vårdenheter sattes upp i Guinea i samband med ebolautbrottet 2014 lades fokus på säkerhet inriktad på att spara liv (bio-security) i syfte att försöka få kontroll över viruset. I och med detta förlorades, enligt Veronica Gomez-Temesio (2018), livsetik (ethics of life) och patienter reducerades till farliga kroppar. Döda kroppar blev liggande, döende patienter bortom räddning negligerades, personal gick in i rum där smittade eller sådana som väntade på resultat vistades så sällan som möjligt etcetera. Isoleringen av ebolasmittade människor ledde till att de sociala banden upphörde, vilket innebar att de isolerade upplevde social död innan sin biologiska död och därmed hamnade $\mathrm{i}$ ett gränstillstånd mellan liv och död. De blev, med Gomez-Temesios ord, "zombier"; fortfarande vid liv, men betraktade som döda. I en artikel om ebolans psykosociala effekter (Van Bortel, Basnayake, Wurie m.fl. 2016) beskrivs hur den isolering som sjuka och döende utsätts för kan innebära ökade känslor av sorg, stress, skuld och hjälplöshet hos dem som inte kan vara vid sina anhörigas sida. I slutet av artikeln diskuterar författarna behovet av psykosocial omsorg i kölvattnet av ebola men uppmärksammar också de positiva effekter epidemin medförde i form av gemenskap, handlingskraft och resiliens (se även Wettergren, Holmes \& Manning 2020).

I en rapport om covid-19 från Folkhälsomyndigheten (Fohm 2020) lyfts att välbefinnandet hos befolkningen i ett antal länder - dock inte Sverige - har minskat under covid-19-pandemin och att stress och psykisk ohälsa verkar vara högre bland dem som tillhör en riskgrupp, själva har varit sjuka eller haft en närstående eller bekant som varit sjuk (se även Kulin, Johansson Sevä, Hjerm m.fl. 2021 i detta nummer). Trots att en undersökning från maj 2020 visar att den självrapporterade psykiska hälsan är oförändrad i Sverige, så menar Folkhälsomyndigheten att fler forskningsstudier av god kvalitet behövs samt att proaktiva åtgärder är nödvändiga (Fohm 2020). Vår studie är ett bidrag till kunskap om hur covid-19 påverkar människors psykiska välbefinnande, med ett specifikt fokus på de som har förlorat nära anhöriga. I vår studie är det dock inte enbart anhöriga till personer som avlidit på grund av covid-19 som inkluderas, utan också anhöriga till personer som avlidit av andra orsaker. Vi menar att den specifika erfarenhet som restriktioner om fysisk distans medför är liknande mellan dessa grupper.

Mer forskning efterfrågas även i tidigare statliga utredningar om död och anhörigas erfarenheter. I Döden angår oss alla. Värdig vård vid livets slut nämns särskilt forskning om palliativ vård samt döden mer generellt. Vidare nämns vikten av forskning om anhörigas psykosociala hälsa, arbetsbelastning och möjlighet till värdiga avsked och 
goda minnen (Kommittén om vård i livets slutskede 2001:63, 90). Vår studie svarar på delar av detta forskningsbehov.

\section{Metodreflektioner}

Intervjupersoner rekryterades till vår studie genom en kontaktenkät på internet som distribuerades genom sociala medier. Här användes både forskarnas egna nätverk och universitetets, dock var det från de egna nätverken som flest svar kom in. I enkäten ställdes frågan om man hade haft någon nära anhörig som avlidit eller varit i livets slutskede under den tid som restriktioner på grund av covid-19 funnits, samt om man ville låta sig intervjuas om sina erfarenheter. Urvalsmetoden innebär att vi inte kunnat nå människor i alla samhällsgrupper. Av dem vi intervjuat är de flesta högutbildade, majoriteten är kvinnor och samtliga talar god svenska. I slutdiskussionen återkommer vi till vad det kan innebära för våra slutsatser.

Analysen baseras på nio kvalitativa individuella intervjuer som genomförts via videosamtal, telefonsamtal eller ansikte mot ansikte och spelats in. Intervjuerna var semi-strukturerade med en intervjuguide, men de intervjuade hade stort utrymme att forma intervjun utifrån sina erfarenheter och reflektioner. Syftet med intervjuerna var att få fördjupande och komplexa berättelser om hur relationer, omsorg och avsked påverkats av restriktionerna, samt vilka känslor det väckt. Intervjuerna varade mellan en halvtimme och en och en halv timme (de flesta en dryg timme) och samtliga har transkriberats. I ett inledande analysskede skapade vi "fallbeskrivningar", där varje intervju i sin helhet sammanfattades. I tematiserings- och kodningsfasen utgick vi från våra frågeställningar, men förhöll oss också öppna inför uppkomna teman.

Vi har båda tidigare mest intervjuat ansikte mot ansikte och hade en del farhågor inför att göra digitala intervjuer eller via telefon, särskilt med tanke på att ämnet kan uppfattas som extra känsligt att tala om. Vi upplevde dock att samtalen var förtroendefulla och intervjupersonerna delade generöst med sig av sina erfarenheter, tankar och känslor. I slutet av intervjuerna uttryckte flera att det var skönt att få prata om dessa saker, att det upplevdes som tillfredsställande att komma i kontakt med sina känslor och att det generellt finns för få rum där man kan prata om döden. Vi funderade också mycket över de etiska aspekterna av att intervjua någon som potentiellt befinner sig i kris och därmed riskerar att hamna i ohanterliga situationer. Vi var därför väldigt noga både inför och under intervjuerna med att klargöra vår roll som forskare och deras ansvar för att enbart prata om det som de ville och kunde prata om. I övrigt har alla sedvanliga etiska aspekter beaktats och studien har godkänts av Etikprövningsmyndigheten. Inga namn eller andra detaljer som kan avslöja den intervjuades identitet finns med i föreliggande text, samtliga har gett skriftligt samtycke till att medverka i studien och har informerats om sin rätt att när som helst dra sig ur. Vidare har de medverkande fått information om datahantering och sekretess.

Yasmin Gunaratnam (2012; se även Ahmed 2002) påminner oss om att även om vi som forskare är berörda av och öppna för lidande så bör vi vara ödmjuka inför att vi aldrig fullt ut kan förstå och beskriva smärta, lidande och sårbarhet. Hon hävdar att 
smärta "förstör" språket, vilket gör det svårare att tolka människan som lider. Detta leder henne till att tala om ett brobyggande arbete mellan sociologisk uppmärksamhet och metodologisk improvisation. Samtidigt varnar hon för mystifiering av "det obegripliga", och uppmanar oss att försöka förstå lidande ur olika perspektiv. I vårt fall har det bland annat handlat om ett medvetet empatiskt lyssnande där vi prioriterat att följa intervjupersonernas "berättelsebehov" och vara emotionellt närvarande snarare än att inta en traditionell forskarposition. Holmes (2015) påminner oss om att många känslor kan vara svåra att sätta ord på och visa i en intervjusituation, att känslor kan döljas medvetet eller omedvetet och att känslor ofta är motstridiga och därför svåra att visa eller prata om. Intervjuerna utgörs av berättelser och har därmed en narrativ struktur. I berättelsen byggs mening upp utifrån det tidigare sagda. Därmed blir hela berättelsen en kontext som bidrar till förståelsen av delarna. Berättelser är enligt Jochen Kleres (2010) emotionellt strukturerade och genom berättelsens gestalt framträder emotionerna. Kleres argumenterar för att berättande inte bara handlar om att kognitivt legitimera sina känslor utan även om att genom berättelsen och lyssnarens empati dela sina känslor och genom det väcka förståelse. Att empatiskt lyssna till berättelsen och förstå berättelsens delar genom dess kontext har därför varit vår metod för att analysera berättelsernas emotionalitet och emotioner. På samma sätt som berättelsen kan förmedla mer än vad berättaren själv förstått, genom att berättaren vet hur något kommit att hända även när hon inte analyserat varför det blev så, kan den också förmedla de känslor som berättaren ännu inte satt ord på.

\section{Berättelser om att ta avsked i coronatider}

I detta avsnitt analyserar vi de berättelser vi tagit del av. I intervjuerna möter vi både de som fått ta avsked som de velat och de som inte kunnat ta avsked på grund av restriktioner i samband med covid-19. Oavsett vilket, så uttrycker de liknande förväntningar på och normer kring "det goda avskedet". Föreställningar om att vara närvarande vid dödsstunden genomsyrar samtliga berättelser. De intervjuade använder ord som "man ska ta farväl på riktigt sätt", "hade vi följt mallen och varit där så hade det blivit värdigt och fint", "man ska sitta där när den anhöriga tar sitt sista andetag" och "man ska vara med i den processen". Analysdelen är disponerad utifrån olika aspekter av denna närvaro: Ingen ska behöva dö ensam; Förklara sin kärlek; Vara den döendes röst; Gemenskap med nära och kära och gemenskapens gränser; samt Delaktighet i vad som sker. Genomgående analyseras intervjupersonernas tal om erfarenheter, emotioner och emotionsarbete med hjälp av begreppen interaktionsritual, empatiska föreställningar och tillit.

\section{Ingen ska behöva dö ensam}

Den aspekt av närvaro vid dödsstunden som framstår som mest central i intervjuerna är att de anhöriga hade velat vara där för den döendes skull; ingen ska behöva känna sig ensam eller övergiven när hon dör. Närvaron av en nära anhörig antas kunna verka tröstande, lugnande och i vissa fall också hjälpa den döende att dö.

I en intervju berättas om en mormor som dog på sitt äldreboende utan någon anhö- 
rig vid sin sida. Mormodern fick feber (senare konstaterad covid-19) och de anhöriga ville komma dit och träffa henne, men avvisades med hänvisning till restriktioner som införts i samband med covid-19. De bad att åtminstone få prata med mormodern på telefonen, men personalen hade inte tid, de "gick på knäna" på grund av ett stort antal andra lika sjuka boenden på hemmet.

Intervjupersonen sörjer att det gick till som det gjorde och att de inte fick ta farväl. Framför allt plågas hon av att mormodern var helt ensam den sista tiden. Hon undrar också om personalen under en period undvek att gå in till mormodern eftersom hon kanske hade covid-19 och de inte hade tillräckligt med skyddsutrustning. Oklarheten i detta beror på att det var intervjupersonens mamma som hade den huvudsakliga kontakten med personalen och att intervjupersonen inte är säker på att det stämmer att personalen undvek att gå in till mormodern. Under mormoderns sista 45 minuter i livet närvarade en ur personalgruppen, men intervjupersonen vet inte vem det var. Osäkerheten skapar stort utrymme för empatiska föreställningar om hur det kan ha varit. Föreställningarna pendlar mellan å ena sidan att mormodern dog lugnt och tryggt med en person ur personalen vid sin sida och å andra sidan att mormodern kände sig övergiven och led av dödsångest. Upprättande av tillit till personalen blir centralt, men försvåras av att intervjupersonen visste att personalen inte kunde vara där så mycket som de ville på grund av mycket hög arbetsbelastning.

De intervjuade uttrycker att det spelar roll om det är en anhörig eller en person ur personalen som sitter vid den döendes sida. Flera av dem som fått tillåtelse att besöka sina anhöriga berättar att de talade om bekanta saker, minnen och att blotta närvaron av deras bekanta röst förhoppningsvis fungerade lugnande. En av de intervjuade berättar om ett avsked som upplevdes positivt och tillfredsställande; det blev i stort sett så som intervjupersonen önskade att det skulle bli. Den sjuka mamman vårdades i hemmet där hon bodde med sin make. Hemtjänst och ASIH (avancerad sjukvård i hemmet) arbetade där och alla anhöriga kom och gick som de ville. Mamman låg i en säng i vardagsrummet för att alla skulle få plats och för att hon skulle kunna titta på teve. Under de dygn då mamman dog var alla närvarande. De åt tillsammans, turades om att sova och pratade om gamla minnen och tittade på foton tillsammans. Intervjupersonen säger att mamman mestadels sov på grund av morfinet men att om hon skulle ha vaknat så skulle hon hört bekanta röster som talade om saker hon kände igen sig i. Intervjupersonen uttrycker stor tacksamhet över att de fick förmånen att vara delaktiga i både döendeprocessen och avskedet på detta sätt. Samvaron kring dödsbädden kan betraktas som en interaktionsritual som gav de sörjande emotionell energi och stärkte deras gemenskap och identifikation som "en familj”. Den döende var deras gemensamma fokuspunkt och de kunde odla känslan av att tillsammans göra det som familjen betraktade som rätt och gott. Normer om familjegemenskap reproduceras och i berättelsen framkommer också att de som räknas som familj är de närmaste släktingarna, inte vänner eller mer avlägsna släktingar (se t.ex. Butler 2006).

I en intervju berättas om en föreställd interaktionsritual - som också den fungerar gemenskapande. Den dementa pappan med konstaterad covid-19 dör på ett äldreboende utan de anhöriga vid sin sida. Intervjupersonens mamma hade bett personalen 
att om mannen undrade var hon var, svara att hon nyss varit där och bara gått hem en stund, och personalen hade då hade svarat: "Jag behöver inte säga det till honom, för han tror att du är här, han pratar med dig hela tiden." Intervjupersonen uttrycker lättnad över detta: "Han hade mamma där även om hon inte fick vara där. [...] Jag kan inte veta om det verkligen var så eller om det var något personalen bara sa. Men för mig känns det bättre.” Dessa empatiska föreställningar om att pappan inte kände sig ensam möjliggörs av hennes tillit till personalen.

Avskedstagande via telefon beskrivs i en intervju som ett alternativ till att vara fysiskt närvarande. Intervjupersonen kunde inte vara på plats när hennes multihandikappade syster dog på sjukhus. När vi pratar om själva avskedet och vad det betyder säger hon:

Jag hade naturligtvis inte velat något annat än att vara där. Så därför är det här, att jag faktiskt fick höra hennes röst eller prata med henne två gånger innan hon dog, det väger jättestort. Men det var ingenting som de erbjöd. [---] Men då hade jag möjlighet att säga det där man gör när man sitter med någon som är döende [---] då hälsar man från alla och man liksom "vi tänker på dig, det ska nog gå bra”. Allt det där som man säger när man sitter och håller handen och man inte riktigt vet om den andra hör, eller är medveten. Det kunde jag säga till syrran i telefonen. Och eftersom hon gav det där lilla ljudet så vet jag att hon hörde det. Så det var jätteviktigt. [...] Jag är fruktansvärt glad för att jag kunde säga de där tröstande orden då. Det var det jag hade gjort om jag varit där, så hade jag hållit henne i handen och det kunde jag inte göra. Jag har bestämt mig för att jag tror på att personalen gjorde det då.

Interaktionsritualen sker på distans vilket inbegriper ett stort mått av empatisk föreställningsförmåga. Hon föreställer sig hur hon håller sin syster i handen och - eftersom hon vet att det inte sker - så fantiserar hon om hur personalen håller systerns hand när hon dör. I berättelsen blir det också tydligt hur viktig upplevelsen av att nå fram är. Hon säger att hon vet att systern hörde henne. Det fanns någon att ha en interaktionsritual med. Samtidigt gav den fysiska distansen upphov till skuldkänslor hos henne. Det var hon som valde att inte komma dit, men beslutet föregicks av motsägelsefulla besked från läkaren: i ena stunden fick hon inte komma på grund av att avdelningen hade covid-19-sjuka patienter, i nästa stund fick hon komma, men vågade inte av rädsla för att själv bli sjuk. Även om beslutet var baserat på motsägelsefulla besked från sjukvården så beskriver hon detta som det svåraste med alltihop: "Jag skulle ha varit där varenda sekund annars. [...] Jag har tagit hand om henne hela mitt liv.".

Förmåga att upprätta tillit till personalen är centralt för dem som inte kunnat eller fått vara närvarande vid dödsstunden. I ett fall blev detta ytterst svårt. Intervjupersonen fick inte någon information alls om sin mammas två sista dygn på äldreboendet, vilket föranledde stor oro: "Mamma och jag som stått varandra så nära. Och så kände jag så här: Undrade hon inte vart jag var? Som att jag hade övergett henne, sådan tanke fick jag då, eftersom jag inte var närvarande när hon gick bort då." Hon hoppas att mamman dog i sömnen och tror att det måste stå något om det $\mathrm{i}$ journalen för " det 
har väl varit någon där och tittat till henne och så”. Genom att föreställa sig att någon måste "ha varit där" försöker hon upprätta tillit till personalen och skapa en levbar berättelse om det hon inte vet något om. Hon säger att hon önskar att hon i alla fall hade fått vara med via telefon när mamman dog. Hon föreställer sig att ljudet av hennes röst skulle kunna ha hjälpt mamman, kanske lugnat henne.

En intervjuperson uttrycker stark glädje, nästan eufori, över att ha nått fram till sin gravt dementa och mycket oroliga mamma och hjälpt henne att bli lugn inför döden och att släppa taget och dö. När han blev ensam med henne satte han sig ned hos henne och pratade om vilken bra mamma hon varit och hur härligt de haft det på sitt lantställe genom alla åren. Han sa också att hennes föräldrar väntade på henne och ville att hon skulle komma. I intervjun beskriver han hur mammans andetag plötsligt blev lugnare och att hon slappnade av, hur hon tog några djupa andetag och dog:

Hon hörde allting jag sa. Jag är så jävla tvärsäker på att hon hörde precis allting jag sa. Det var så jävla coolt på något sätt, att jag fick henne... för hon hade legat och kämpat där i nästan fem dagar och sedan bara jag talade om för henne ”det är okej, alltså du behöver inte ligga här och kämpa för vår skull, utan du får lämna nu, om det är jobbigt, det finns folk som väntar på dig”. [...] Hon hörde vad jag sa, jag är helt övertygad om det. Någonstans där långt därinne så hörde hon vad jag sa.

Euforin och glädjen bör förstås dels som utlöst av det faktum att han genom iscensättandet av en interaktionsritual hjälpte henne i en existentiellt viktig stund, dels i kontrast till flera år av att inte alls ha nått fram till henne - det vill säga flera år av uteblivna interaktionsritualer.

De som kan berätta om goda avsked, om hur de lyckats ordna det på ett sätt som de är nöjda med, uttrycker tacksamhet och stolthet. Ofta har de varit väldigt aktiva och involverade i arrangemangen och har "offrat" något för att skapa det avsked de velat ha eller ge. Till exempel har de flyttat in till den döende, sovit för lite, rest långa vägar, ombesörjt ett nytt hem för husdjur, suttit många timmar bredvid någon som inte varit vaken och, inte minst, tagit risker i förhållande till att bli smittade med covid-19. De har gått in på äldreboenden som varit hårt drabbade av viruset, de har i vissa fall klätt på sig skyddsutrustning, i andra fall inte. I den existentiellt viktiga situation som döden innebär framstår andra saker i livet som mindre viktiga, och de anhöriga får en sista chans att visa omsorg.

\section{Förklara sin kärlek}

I några av intervjuerna lyfts vikten fram av att vara känslomässigt närvarande och ge en sista kärleksförklaring eller omsorgshandling. Att säga en gång till hur mycket de älskar personen som ska dö framställs som en specifik handling. Även om de sagt det innan så verkar det som att det kan eller bör sägas på ett annorlunda sätt när döden är mycket nära; mer närvarande, med mer kraft och riktning och kanske till och med mer uppfordrande. 
En intervjuperson som inte fick närvara alls vid sin svärmors döende och död berättar om hur hon hade velat förmedla sin kärlek:

Det är inte bara för min skull, jag älskade verkligen henne. [...] Jag skulle vilja säga en gång till vad värdefull hon är. Jag sa ofta det till henne [...] Jag skulle verkligen vilja spänna ögonen i henne en gång till och säga det. Och vad viktig hon har varit, och vad mycket hon har bjudit på sig själv och sin humor.

När vi frågar kvinnan vars mormor dog ensam på äldreboendet vad sorgen i det förlorade avskedet handlar om svarar hon: "Att jag inte fick säga till mormor att jag älskar henne innan hon dog. Så att hon fick ta det med sig. Helt enkelt”. En intervjuperson berättar om skuld över att hon inte tagit kontakt när hon via ett inlägg på sociala medier anade att en vän skulle dö:

Efteråt så funderar man så mycket: "Åh, varför skickade jag inte någon hälsning? Varför gjorde jag inte någonting?” Men det fanns nog inte i min värld att hen skulle dö. [...] För det var någon form av... ja, men dödsångest, någon fundering över döden. Den var närvarande för hen på Facebook. [...] Hade jag kunnat gjort något mer?

I dessa exempel handlar det om uteblivna interaktionsritualer och hur denna brist ger upphov till känslor av sorg och skuld. I stället för att ingå i en social interaktion som, om den är lyckad, skapar emotionell energi, solidaritet och bekräftelse av jaget, står dessa personer ensamma med sina kärleksbudskap.

Skuld är något som konstrueras utifrån empatiska föreställningar; vi föreställer oss att någon vi bryr oss om och känner ansvar för lider eller behöver något och när vi inte kan vara där och trösta och tillfredsställa dessa behov känner vi bland annat skuld över det (Stolinski, Ryan, Hausmann, m.fl. 2004). Skuld manifesteras i vårt material ofta genom frågor som ställs till det egna jaget: Sa jag tillräckligt? Visade jag tillräckligt? Kände hon sig övergiven av mig? Varför skrev jag inte till henne? Det är frågor som ingen annan kan svara på och som förmodligen inte ens är möjliga att besvara. Frågorna är i sig skuldskapande, vilket leder till ett slags självgenererande effekt. Skuld verkar vara ett uttryck för osäkerhet över den egna tillräckligheten snarare än en självklar upplevelse av otillräcklighet. De av våra intervjupersoner som inte fick närvara på grund av restriktionerna uttrycker skuldkänslor i mindre utsträckning eftersom det inte var deras beslut att inte vara där. De känner sig ändå maktlösa och otillräckliga eftersom de inte kunde ta det ansvar som de uppfattade som deras.

\section{Vara den döendes röst}

En annan aspekt av det goda avskedet handlar om att ta ansvar för den som är skyddslös och sårbar, bland annat genom att vara den döendes röst. När människor är döende förlorar de ofta sin förmåga att kommunicera, de blir orkeslösa eller så sederade att de inte längre är vakna. Om en anhörig som känner den döende väl är där så kan den 
berätta för vårdpersonal om hur den döende vill ha det och eventuellt tolka subtila signaler från den döende. I samband med att vi för någon annans talan blir empatiska föreställningar aktuella på ett mycket påtagligt sätt. Vi måste på ett empatiskt sätt kunna föreställa oss den andres behov, trots att vi kanske inte vet helt säkert vad den andre känner, vill och behöver. Ibland handlar det också om ren kunskap om och erfarenhet av den sjuka och hennes situation.

Detta blir extra viktigt för personer som redan från början befinner sig i en sårbar position, som i fallet med den multihandikappade systern. Eftersom personalen på sjukhuset inte förstod systerns sätt att kommunicera kunde de inte avgöra om hon var vid medvetande eller inte, så intervjupersonen blev uppringd ett antal gånger för att förklara och hjälpa till att tolka ljud från systern. Det faktum att det räckte med ett kort telefonsamtal mellan intervjupersonen och systern för att klargöra frågan om medvetandegrad visar hur betydelsefull en anhörig kan vara.

En kvinna berättar om hur hennes man en dag åkte in akut med andnöd och var så dålig att han knappt kunde prata. Hon fick inte följa med på grund av covid19-restriktionerna och minns hur det var när hon såg honom för sista gången:

Han kom och fick satt sig på båren, men han orkade inte ta upp benen. De tog överkroppen och jag fick lyfta upp honom och så. Och sedan ser jag honom när de sätter in honom i ambulansen, då ligger han där...sitter gör han, eller halvsitter. Och så med syrgasen. [...] Det var inte så att man vinkade precis.

Under dagen ringer hon upprepade gånger till sjukhuset för att få information om hur det går, men inte förrän på kvällen blir hon uppringd av läkare som låter henne förstå att de närmast anhöriga måste komma dit. Väl där får de veta att inget finns att göra och tillsammans bestämmer de sig för att koppla ur respiratorn. Hon uttrycker besvikelse och sorg över att hon inte kunnat vara där och föra hans talan: "Han orkade inte prata heller då, så mycket. Så man kanske hade kunnat prata med någon [...] träffat läkaren.”

En intressant aspekt av interaktionsritualen när någon för någon annans talan är den komplexitet som uppstår när den anhöriga både är där i egenskap av sig själv och i egenskap av ställföreträdare. Den anhöriga får på så sätt axla flera roller i interaktionen. Även en sådan interaktionsritual kan dock vara lyckad och ge emotionell energi, något som blir tydligt i berättelserna ovan. Kvinnan som kunde föra sin systers talan, även om det var via telefon, uttrycker en viss tillfredsställelse, medan kvinnan som inte kunde föra sin makes talan alls uttrycker besvikelse och tomhet.

\section{Gemenskap med nära och kära och gemenskapens gränser}

Inför döden aktualiseras en rangordning av relationer där familj och släkt har företräde framför vänner, något som diskuterats inom forskning om normativt släktskap och den utvidgade familjen (Henriksson 1995; Butler 2006). Detta får effekter på möjligheten till avsked och rätten att sörja, något som tidigare forskning (Doka 1989, 2002) talar om i termer av disenfranchised grief, det vill säga sorg som inte erkänns som legitim. 
Sorgeregler privilegierar den traditionella heterosexuella familjen och erkänner inte till exempel homosexuella partner, ex-partner, vänner, arbetskamrater och husdjursägares sorg fullt ut (Doka 1989, 2002; McNutt \& Yakushko 2013). I vårt material framkommer denna icke erkända sorg tydligast hos en intervjuperson som varken fick närvara vid sin transsexuella väns begravning eller ta avsked av sin svärmor. Bara de allra närmaste familjemedlemmarna bjöds in till begravningen av vännen. Intervjupersonen funderar över om detta uteslutande av alla vänner enbart handlade om covid-19 och smittskydd eller om det också handlade om att den döda var en transperson och att familjen genom uteslutandet av vänner höll det queera livet på avstånd från begravningen. Exkludering från en så existentiellt viktig interaktionsritual som en begravning är något många fått och fortfarande får erfara i pandemitider, men i detta fall, när osäkerhet uppstår kring orsakerna till exkluderingen, får det andra konsekvenser. Exkluderingen kanske inte är generell utan möjligtvis specifik, något som beror på maktordningar och därmed drabbar människor ojämlikt. Samma intervjuperson lever i ett särboförhållande med en annan kvinna och hon berättar att hon under samma tidsperiod även förlorat sin svärmor, som hon stod mycket nära, utan att få vara delaktig vare sig innan, under eller efter själva dödsfallet. Exkluderingen förklaras först med hänvisning till att de inte ville riskera att smitta den sjuka svärmodern, sedan med att endast en besökare tilläts på hospis. Hon ger uttryck för sorg, smärta och ilska över att inte räknas som nära anhörig trots att hon känner sig som det. Genom att leva i en samkönad relation och genom särboendet bryter hon mot flera familjenormer. Hierarkier kring anhörigskap och brott mot familjenormer exkluderar henne samt gör henne till en icke-legitim sörjande.

Flera av de intervjuade ger uttryck för att de saknade att få samlas kring sin döende anhöriga. Även en intervjuperson som fick vara på plats hos sin pappa beskriver hur hon inte borde suttit där ensam. Avskedet blev inte en gemensam händelse som hon kunde dela med bröderna - eftersom de inte vågade komma på grund av smittorisken. Interaktionsritualen och den gemenskap och det stöd som den hade kunnat erbjuda uteblev, vilket skapade en känsla av tomhet och besvikelse. Också i fallet med kvinnan vars man åkte in akut med andnöd blir det tydligt hur de inte fick till stånd avskedet på det sätt hon önskat. På grund av covid-19 fick de anhöriga inte komma in till avdelningen förrän väldigt sent i döendeprocessen. De fick därför endast tio minuter med maken och pappan innan han dog. Han var då medvetslös och de satt runt honom och klappade honom. Trots att de satt samlade - och faktiskt hade en interaktionsritual - är det som om att den inte riktigt räknas. Mannen var medvetslös, tiden var kort och ett av barnen kunde inte närvara på grund av smittorisken. Förväntningar på "det goda avskedet" uppfylldes inte och därmed uppstod inte den interaktionsritual som "skulle ha varit" och som kunde ha gett de medverkande emotionell energi.

Trots att hon ger uttryck för att allt blev så bra som det kunde bli efter omständigheterna så känner en intervjuperson sorg över att hon och familjen inte fick vara där och ta farväl av pappan när han dog på ett äldreboende: 
Att vi skulle ha varit där, jag och mamma och brorsorna. Och varit hos honom när han dog. Den bilden fanns. Men... så kunde det inte bli. Och det är en tagg att vi inte sa hejdå. Det är det. [...] Det är ingen kritik på något sätt mot beslutet som togs på boendet att inte ta dit oss, utan det är en... ja, ett litet personligt glapp i hjärtat, att där blev det inte fullbordat riktigt. [...] Att vi hade varit i rummet och stöttat varandra och pratat med pappa och pillat litegrann på honom och sagt adjö.

Hon beskriver hur avsaknaden av samvaro kring dödsbädden gör att dödsfallet känns lite mindre konkret och hur hon saknar att ha fătt krama om de andra i familjen och kunna ge och få stöd från dem. Den fysiska kontakten och delandet av stunden är en viktig del i en lyckad interaktionsritual.

Döden framställs alltså också som en möjlighet att samlas och visa omsorg om varandra. Det handlar om att skapa sammanhållning genom att delta i interaktionsritualer i en existentiellt avgörande situation. Gemenskapen blir också ett sätt att hantera den egna oron och sorgen, att med "egna ögon" se hur de andra klarar av situationen och att både kunna ge och ta emot stöd. Kanske handlar det också om det som Gunaratnam (2012) beskriver: det finns smärta som inte kan förklaras eller lindras, utan som bara måste genomlevas och att omgivningens uppgift är att vara vittnen, att finnas där, stå bredvid och se tillsammans (se också Ahmed 2002). När man inte får komma in, eller när det är för riskabelt att komma in, berövas man den interaktiva ritual som det är att vittna samt sitta och vaka tillsammans.

Gemenskap och att dela situationen med flera anhöriga är dock inte det enda ideala sättet att ta farväl på. Det kan också vara viktigt att få en stund ensam med den som dör. Mannen som hjälpte sin mamma att "släppa taget" berättar att han förmodligen inte hade kunnat genomföra avskedet på det sätt han gjorde om han inte hade varit ensam med mamman. Han säger att det annars hade känts lite pinsamt, men framför allt menar han att de andra i familjen kanske inte skulle tyckt att det var rätt av honom att säga att hon fick dö: "På något sätt så var det mycket lättare att vara så där personlig som jag var med morsan när jag var ensam med henne". Den interaktionsritual han såg framför sig med de andra i familjen skulle alltså riskera att ödelägga den tillfredsställande interaktionsritual han skapade med sin mamma. Kanske föreställde han sig att han skulle ha anpassat sig till de andras sätt att ta farväl och därmed förlorat möjligheten till det avsked han nu fick till stånd. Ett annat exempel är en intervjuperson som säger att det var viktigt för henne att få en egen stund med mamman efter att hon dött, där ingen annan var närvarande, för att hon inte "ville ha publik" utan låta deras egna "relationsdynamik" få utrymme - en relationsdynamik som med hjälp av empatisk föreställning alltså fortsätter även efter att döden inträtt. I båda dessa fall framträder gemenskap kring dödsbädden som en tvingande norm för den som vill vara själv med den döende. Önskan om intimitet och avskildhet vid dödsbädden utmanar således gemenskapsidealet. 


\section{Delaktighet i vad som sker}

Ytterligare en aspekt av vikten av närvaro som framkommer i materialet handlar om delaktighet som hjälp för den efterlevande. Genom att vara delaktig i döendeprocessen och få information så antas den anhöriga bättre förstå vad som händer och kunna ta in det. Döden blir då inte en så chockartad och skrämmande upplevelse som den kan bli om den anhöriga inte hade fått närvara, eller ens fått veta att den närstående var döende. Den egna erfarenheten av hur döendet tar ifrån den döende förmåga efter förmåga verkar starta en särskild sorts meningsskapande process hos den anhöriga. De som inte fått vara med uttrycker känslor av chock, tomhet och att ha blivit bestulna på något mycket viktigt. De uttrycker också oro inför hur de döende kan ha haft det. Oro över att de farit illa genom att ha varit ensamma, övergivna, oförstådda, att de blivit felbehandlade, haft ont eller lidit av oro och ångest. De som inte kunnat närvara alls uttrycker mest oro. Ovissheten öppnar för empatiska föreställningar om hur illa det kan ha varit, vilket gör det svårt att skapa tillit och en känsla av att det blev så bra som det kunde bli - givet omständigheterna. Utebliven kontakt med vårdpersonal - att inte få svar på telefonsamtal, att inte få veta, att inte bli inkluderad genom information - har utlöst kraftig oro hos några av intervjupersonerna och krävt stor ansträngning för att upprätta tillit.

En av intervjupersonerna, som hade en mycket nära relation med sin mamma och som innan covid-19-restriktionerna besökte henne en eller två gånger i veckan på äldreboendet, berättar om hur hon inte fick någon information alls om mammans sista dagar i livet, då hon hade fått konstaterad covid-19. Hon hade vid ett tillfälle kontakt med mamman via telefon och hörde hur hon var "lite tungandad". Sedan blev det tyst. Hon berättar att hon ringde minst tio gånger till avdelningen nästa dag och till mammans mobil. Inga svar. Dagen efter ringde hon igen upprepade gånger och personalen svarade till slut. De kunde dock inte svara på frågor om hur mamman mådde utan hänvisade till sjuksköterskan som sedan visade sig vara sjuk. Intervjupersonen försökte tänka: "Inga nyheter är goda nyheter" och avstod från att fortsätta jaga personalen. Sent på kvällen ringde de och berättade att mamman avlidit. Intervjupersonen beskriver det som en chock: "Det var fruktansvärt." Eftersom hon inte fått någon information från äldreboendet och inte ens fått se mammans journal vet hon inte hur mamman mådde den sista tiden och om det var någon där hos henne när hon dog. Äldreboendets agerande påverkar hennes sorgeprocess:

Det är så dåligt så det är, usch. Det blir något som gör att man sörjer på ett annat sätt också, alltså det är svårare, ja, jag kan inte förklara, men det sitter där hela tiden. [...] Detta att jag inte fick veta att hon var så sjuk. Varför ringer man inte och säger det till mig? [...] Den [processen] blir så utdragen känner jag på något sätt. Jag tror inte jag får lugn förrän jag har fått journalen och jag har fått utlåtandet från Patientnämnden. [...] Varför ringer ingen till mig? Det mal i huvudet. Jag menar, jag ringde så många gånger. [...] Jag känner mig sviken, de har tagit något ifrån mig. Jag är bestulen på något sätt. 
De anmälningar till Inspektionen för vård och omsorg och Patientnämnden som hon har gjort har blivit centrala för hennes möjlighet att bearbeta mammans död. Hon anser att fel har begåtts och genom att anmäla överklagar hon till en högre instans för att få upprättelse för dessa fel. När äldreboendet inte erkänner hennes önskemål, och därmed hennes känslor, som legitima behöver hon söka vidare efter ett sådant erkännande för att kunna gå vidare. Eftersom hon inte fått den information hon önskat - ens i efterhand - blir det också svårare för henne att upprätta tillit till personalen. Den tillit hon hade när hon avstod från att jaga personalen via telefon har brutits. Enligt Barbalet (2009) väcker brusten tillit inte bara ilska mot den andre utan också självförebråelse och dåligt samvete för att man själv missbedömt den andres pålitlighet. Kanske är en del av intervjupersonens frustration uttryck för en besvikelse på sig själv - fast hon inte hade någon möjlighet att göra annorlunda, vilket förstärker känslan av maktlöshet.

I ovisshet finns dock också en möjlighet att, i brist på information om hur det var, göra sin egen berättelse, en fantasi som ligger så nära idealet som möjligt och därmed blir mer möjlig att stå ut med känslomässigt. Ett exempel på detta är kvinnan vars multihandikappade syster dog utan sin anhöriga vid sin sida. Läkaren hade sagt att personalen skulle sitta med systern. Hon ringde flera gånger för att höra hur det gick, men det var upptaget. När hon till slut fick kontakt meddelade de att systern avlidit. Hon berättar: "Jag ville veta när hon dött, men det kunde de inte berätta." För att få en version av det som hänt som hon kan leva med bestämmer hon sig för att tolka upptagetsignalerna som att de var upptagna med systern, att de skötte om henne, att de var vid hennes sida när hon dog. Hon upprättar tillit till personalen också genom att beskriva hur hon sett att en av läkarna visat omtanke om systern i en annan situation och att han därmed var en person som inte skulle låta systern dö ensam.

Kvinnan vars mamma dog i hemmet, omgärdad av hela familjen, säger:

Det blir mycket större om man inte är med. [...] Är du med så ser du vad som händer. Du ser att hon blir sämre, du ser att hon slutar äta, du ser att hon slutar dricka. [...] Du är med i processen, som gör att den inte blir lika skrämmande [...] Det blir så overkligt om du inte är på plats, om du inte ser. [...] Man blir mindre alienerad, mindre... ja, frånkopplad från det hela. Då är man med i hela processen. [...] Jag tror att det är den processen som måste vara fruktansvärt om man inte får vara med $i$.

Här understryks betydelsen av att som anhörig delta i och gemensamt erfara dödsprocessen på en konkret och materiell nivå för att kunna förstå och hantera döden när den kommer. I de sista orden ryms också hennes empatiska föreställningar om hur det skulle kunna ha varit, och den lättnad hon känner för att hon slapp vara med om det.

Ett exempel på tillit då informationen från äldreboendet varit god ges i berättelsen om den dementa pappan som dog med en person ur personalen vid sin sida. Intervjupersonen menar att personalen tagit ett välgrundat beslut som gick ut på att skydda både de som bodde där och personalen, men också mamman - mot risken att smittas av covid-19. Både hon och mamman känner stor tillit till och förtroende för 
personalen, något hon menar bland annat beror på att de var så bra på att höra av sig, ge information och rapportera om pappans status. Genom tilliten till att de restriktioner som fanns varit nödvändiga, blir inte hennes och moderns frånvaro ett onödigt lidande utan ett nödvändigt faktum. Genom tilliten till personalen kan hon upprätta känslan av att pappans sista tid blev så bra som den kunde bli.

Intervjupersonerna säger så gott som genomgående att de som arbetat med deras anhöriga varit engagerade och brytt sig om de sjuka och döende, eller i alla fall kan ha gjort det. Tilliten är svårare att upprätta för dem som vet eller anar att personalen samtidigt varit överbelastad - att de antagligen inte kunde göra det de ville göra på grund av tidsbrist eller att de kanske inte hade skyddsutrustning nog för att våga göra det de ville göra.

\section{Avslutande diskussion}

I denna artikel har vi analyserat de normer och föreställningar kring det ideala avskedet som de nio personer vi har intervjuat ger uttryck för samt visat vilka känslor som brott mot respektive infriande av dessa normer och föreställningar ger upphov till. Vi har också diskuterat hur de intervjuade hanterar dessa känslor.

De normer och föreställningar om det ideala avskedet som framkommer i intervjuerna handlar framför allt om att de anhöriga ska vara på plats under döendeprocessen. I flera av intervjuerna hävdas med emfas att ingen ska behöva känna sig övergiven när hon ska dö. De anhöriga ska vara känslomässigt närvarande för att kunna ge stöd och lindra oro hos den som dör, uttrycka sin kärlek en sista gång, prata om minnen och i vissa fall hjälpa den döende att släppa taget och tillåta sig själv att dö. De anhöriga förväntas också fungera som den döendes röst i en situation när hon inte längre själv klarar av att kommunicera. Det omsorgsåtagande som de anhöriga ofta lever med uppfattas som särskilt viktigt att fullfölja i en så skyddslös och sårbar situation som döendet innebär. Kroppskontakt lyfts fram som centralt i denna närvaro; de klappar, tar på, kramar och håller i handen. En annan viktig aspekt av att vara på plats i döendeprocessen är att det hjälper de efterlevande att förstå att döden inträffat och att de därmed får en mer hanterlig sorgeprocess. Ett ideal som kommer till uttryck i materialet är att samla flera ur den närmaste kretsen så att de tillsammans kan stödja varandra och bevittna det som händer - med andra ord delta i de interaktionsritualer som omgärdar döendeprocessen. Genom att dela upplevelsen kan de känna sig samhöriga och till och med få emotionell energi (Collins 2005). I kontrast till detta, ofta familjebaserade, gemenskapsideal framträder ett ideal som handlar om intimitet och avskildhet ihop med den döende/döda. Här är det viktigt att få vara själv med den döende/döda och genom det kunna skapa en önskad interaktionsritual. En och samma person kan ge uttryck för båda dessa ideal och ge utrymme för dem i olika skeenden av döendeprocessen.

De nära anhöriga som bjuds in till avsked och som ges rätt att sörja är oftast personer som ingår i heterosexuella kärnfamiljskonstellationer knutna till den döende eller som har blodsband till den döende. I detta sammanhang uttrycker en av de intervjuade 
stor smärta över att exkluderas från "de närmast anhöriga", att förvägras delaktighet, och att bli vad vi vill kalla en ovärdig anhörig, det som tidigare forskning talar om i termer av icke-legitim sorg, vilket kan resultera i brist på socialt stöd och försvårad sorgeprocess (Doka 1989, 2002). Dessutom, vilket är viktigt när vi diskuterar sorg, så tenderar personer som inte erkänns som legitima sörjande att sörja även det faktum att de utesluts (Kauffman 2002), det vill säga de erfar en dubbel sorg. I materialet har fyra olika familjehierarkier blivit synliga: 1) heteronormativitet där heterosexuella relationer privilegieras på bekostnad av homosexuella, 2) parnormativitet där samboende privilegieras på bekostnad av särboende, 3) distinktion mellan familj och icke-familj där till exempel vänner inte räknas som nära anhöriga, samt 4) familjeinterna hierarkier där make eller maka privilegieras på bekostnad av barn och barn på bekostnad av barnbarn.

För några av de intervjuade infriades flera förväntningar kring avsked. De fick närvara och ta farväl av sina döende nära och kära. Dessa personer uttrycker nöjdhet, glädje, tacksamhet och stolthet. De har, åtminstone delvis, lyckats skapa ett idealt avsked. I ett fall lyckades intervjupersonen samla hela familjen som till en "släktfest" där de satt vid den döendes sida, pratade minnen och åt gemensamma måltider. En annan intervjuperson åstadkom ett idealt avsked genom att nå fram till sin dementa mamma som varit okontaktbar en längre tid och hjälpa henne att släppa taget. Ytterligare en annan berättar om hur hon lyckades komma fram i tid för att hålla sin dementa pappas hand när han dog. Dessa tre personer ger inte uttryck för oro, vanmakt eller plågsamma skuldkänslor - vilket dock inte innebär att de inte känner dessa och andra känslor (Hochschild 1979).

Hos dem vi intervjuat som inte fick ta avsked av sina nära anhöriga på grund av restriktioner i samband med covid-19 har känslor av skuld, oro, vanmakt och djup smärta uppstått. Starkast smärta uttrycker de som inte fått information om hur det gick till när den anhöriga dog, till exempel om det var någon där och hur den anhöriga mådde. Hur de än försökte nå fram till personalen och få information lyckades de inte eller lyckades för sent. De som inte fått någon information tvingas fantisera om vad som hänt, det vill säga använda empatiska föreställningar, i högre utsträckning än de som fått information. Tillit till personalen är central för den empatiska föreställningen om att den anhöriga haft det bra - även när man vet alldeles för lite. Det kan till exempel handla om att de föreställer sig att det fanns någon ur personalen i rummet hos den anhöriga vid dödsögonblicket. Dessa hoppfulla fantasier störs dock av mer hotfulla bilder av den anhöriga som ensam, oförstådd och plågad. Olika empatiska föreställningar slåss alltså om tolkningsföreträde. De intervjuade personerna uttrycker oftast tillit till att restriktionerna varit nödvändiga och viktiga, vilket ger mening åt de uppoffringar de själva fått göra. När tillit inte går att upprätta ökar känslor av besvikelse, maktlöshet och vrede (jfr Barbalet 2009).

Trots att de flesta vi intervjuat skapat sig en levbar sorg och en hanterbar berättelse om det som hänt är det tydligt att smärta är ett fenomen som inte riktigt låter sig arbetas bort. Döden, att mista någon som står en nära, och att även berövas möjligheten att ta farväl och ge omsorg när sårbarheten är som störst, utlöser en existentiell smärta som inget emotionsarbete verkar råda bot på - även om det kan bidra till att göra den 
hanterbar. I detta sammanhang vill vi återknyta till Gomez-Temesio (2018) som skriver om hur människors erfarenheter av lidande alltid undflyr våra teoretiska begrepp. Uppgiften för samhällsvetenskapen är enligt henne att förstå hur kritiska händelser som frågor om liv och död skapar biografier bortom våra begrepp. I linje med detta talar Gunaratnam (2012) om bångstyrig smärta, där smärta sägs göra motstånd mot att "ramas in". Hon menar dock att även om vi misslyckas med att förstå en annan människas totala smärta så är våra försök att göra det viktiga. Sara Ahmed (2002, 2010) hävdar att den plikt att undvika att tala om vår smärta som vi enligt henne lever med gör oss till känslomässiga främlingar (affect aliens) när vi kommunicerar vår smärta. Kanske kan vi tolka det emotionsarbete som intervjupersonerna lägger ned på att hantera sin smärta - också i intervjuerna, i relation till oss - som ett sätt att undvika att bli känslomässiga främlingar. Vidare forskning om smärta orsakad av ofrivillig distans i samband med döende, bland annat i pandemitider, skulle kunna belysa detta ytterligare.

Det finns en intressant metodologisk spänning i vår användning av de två olika empati-begreppen empatisk föreställningsförmåga (Cuff, Brown, Taylor m.fl. 2016) och empatiskt lyssnande. Eftersom empatiska föreställningar alltid innebär just en föreställning om hur det kan vara för den andra så riskerar vi som forskare att höra fel i vårt empatiska lyssnande. I intervjusituationerna har vi försökt motverka detta potentiella "felhörande" genom att ge stort utrymme åt intervjupersonernas berättelser och deras definitioner och förståelser av det som de berättar om. I analysfasen har vi hanterat det genom att sträva efter att ligga nära empirin och undvika vidlyftiga tolkningar av materialet.

Även om vårt urval var relativt homogent finns det skäl att förvänta sig likande normer och emotioner även bland andra grupper i Sverige. Vi kan se att de normer som framkommer i vår analys också är normer som lyfts fram i offentliga utredningar och dokument kring döden. Vi ser också stor samstämmighet bland de intervjuade trots deras inbördes olikheter vad gäller relation till den döende, eget yrke, klassbakgrund, kön och sexualitet. Utifrån att majoriteten av de som ingår i studien är kvinnor är det värt att reflektera över om könade förväntningar kring omsorg och emotioner kan ha haft betydelse för vad som framkommit i vår analys. Att finnas till hands för sina nära och kära när de är sårbara och behövande är generellt ett starkare moraliskt imperativ för kvinnor (Björk 2017), och att inte kunna göra det kan därmed väcka mer känslor av skuld, otillräcklighet och sorg hos kvinnor. Vi såg även i vårt material ett exempel där en intervjupersons bröder inte gjorde samma ansträngningar för att kunna närvara vid dödsbädden.

Precis som i fallet med andra epidemier och pandemier så drabbas vissa grupper hårdare än andra av covid-19 (se t.ex. Rosenfeld, Bartlam \& Smith 2012; Drefahl, Wallace, Mussino m.fl. 2020; SKR 2020; Rostila, Cederström, Wallance m.fl. 2021), både vad gäller antal smittade, antal avlidna och bemötande inom vården. Med tanke på den relativt höga grad av homogenitet som vårt material uppvisar - där vita, svenska kvinnor dominerar - framstår behovet av vidare forskning om ojämlikhetsaspekter av covid-19 med bred variation i urvalet som ytterst viktigt att hörsamma. I denna 
studie har vi visat på betydelsen av att vara en anhörigs röst och att föra dennas talan när hon själv saknar förmåga att kommunicera. För att undvika onödigt många "zombier" (Gomez-Temesio 2018) bör framtida forskning inkludera grupper med särskilda förutsättningar vad gäller kommunikation, till exempel att inte kunna kommunicera med vårdgivare på sitt modersmål.

Vi föreställer oss att den tillit till och samling kring Folkhälsomyndigheten och den "svenska modellen" som vi sett under framför allt första halvan av 2020 kan variera mellan grupper i befolkningen beroende på förmåga att delta i kommunikation på svenska men också på grad av utsatthet i samhället i stort - och i pandemitider specifikt (Kavaliunas, Ocaya, Mumper m.fl. 2020; se även Kulin, Johansson Sevä, Hjerm m.fl. 2021). Tillit till både personal och myndigheter är således också ett område att forska vidare kring utifrån ett explicit maktperspektiv. Det faktum att allt fler delar de upplevelser som analyserats i denna artikel och att pandemin i skrivande stund ännu inte är över (och att fler kan komma), pockar på fortsatta sociologiska analyser. Vi behöver till exempel utforska de etiska dilemman som uppstår när smittskydd har företräde framför mänskliga behov, det som Gomez-Temesio (2018) talar om i termer av biosäkerhet kontra livsetik.

Sverige har länge varit förskonat från kriser som krig, farsoter och katastrofer. I och med covid-19 har vi förlorat den immunitet, den osårbarhet, vi trott oss ha. Döden har trängt in mer i våra liv; många har dött, många har varit nära att dö och många har upplevt försvårande omständigheter när det gäller att ta avsked av döende anhöriga. Antalet döda har upprepats i medierna varje dag. Människor har sorterats in i kategorier som "riskgrupp" - för vilka döden plötsligt framstår som ett mer reellt fenomen. Därmed har vi påmints om vår egna och våra näras dödlighet. Paradoxalt nog har covid-19 samtidigt inneburit att vi har fjärmats från döden (jfr Elias 1985) genom att vi hindrats från att delta i döendeprocessen och ta avsked av våra nära anhöriga när de avlider.

\section{Tillkännagivande}

Vi vill rikta vårt varmaste tack till er som deltagit i intervjuerna och som delat med er så generöst av era erfarenheter och känslor kring att förlora en nära anhörig i dessa svåra tider. Era berättelser är ovärderliga och har berört oss starkt. Tack också till Adlerbertska forskningsstiftelsen för bidrag till omkostnader i samband med denna studie. 


\section{Referenser}

Ahmed, S. (2002) "The contingency of pain", Parallax 8 (1):17-34. https://doi. org/10.1080/13534640110119597

Ahmed, S. (2010) The promise of happiness. Durham: Duke University Press.

Baldassar, L. (2008) "Missing kin and longing to be together. Emotions and construction of co-presence in transnational relationships", Journal of Intercultural Studies 29 (3):247-266. https://doi.org/10.1080/07256860802169196

Barbalet, J. (2009) "A characterization of trust, and its consequences", Theory and Society 38:367-382. https://doi.org/10.1007/s11186-009-9087-3

Björk, S. (2017) Gender and emotions in family care. Understanding masculinity and gender equality in Sweden. Göteborg: Göteborgs universitet, Institutionen för sociologi och arbetsvetenskap.

Björk, S. (2018) "Emotions and empathic imagination. Parents relating to norms of work, parenthood and gender equality", Families, Relationships and Societies 7 (2):171-186. https://doi.org/10.1332/204674317x14861127314323

Bravo, V. (2017) "Coping with dying and death at home. How undocumented migrants in the United States experience the process of transnational grieving", Mortality 22 (1):33-44. https://doi.org/10.1080/13576275.2016.1192590

Butler, J. (2006) Genus ogjort. Kropp, begär och möjlig existens. Stockholm: Norstedts Akademiska Förlag.

Collins, R. (2005) Interaction ritual chains. Princeton: Princeton University Press.

Coronakommissionen (2020) Äldreomsorgen under pandemin. Delbetänkande. SOU 2020:80. Stockholm: Norstedts juridik.

Cuff, B.M.P., S.J. Brown, L. Taylor, \& D.J. Howat (2016) "Empathy. A review of the concept", Emotion Review 8 (2):144-153. https://doi.org/10.1177/1754073914558466

Danielsson, E., F. Liljeros, S. Mulinari \& L. Soneryd (2020) "Sociologiska perspektiv på coronakrisen. Fyra sociologer om samhällets reaktion på covid-19”, Sociologisk Forskning 57 (1):67-76. https://doi.org/10.37062/sf.57.21539

Doka, K. (1989) Disenfranchised grief. Recognizing hidden sorrow. Lexington: Lexington Books.

Doka, K. (2002) Disenfranchised grief. New directions, challenges, and strategies for practice. Champaign: Research Press.

Drefahl, S., M. Wallace, E. Mussino, S. Aradhya, M. Kolk, M. Brandén, B. Malmberg \& G. Andersson (2020) "A population-based cohort study of socio-demographic risk factors for COVID-19 deaths in Sweden", Nature Communications 11:5097. https:// doi.org/10.1038/s41467-020-18926-3

Durkheim, É (1983[1897]) Självmordet. Lund: Argos.

Elias, N. (1985) "The loneliness of the dying", 3-52 i A. Scott \& B. Scott (red.) The collected works of Norbert Elias. Band 6. Dublin: University College Dublin Press.

Fohm (2020) "Påverkar covid-19-pandemin befolkningens psykiska hälsa? En snabb systematisk litteraturöversikt ('rapid review'). Version 1.0” https://www. 
folkhalsomyndigheten.se/publicerat-material/publikationsarkiv/p/paverkar-covid19-pandemin-befolkningens-psykiska-halsa/ (hämtningsdatum 6 oktober 2020).

Gomez-Temesio, V. (2018) "Outliving death. Ebola, zombies, and the politics of saving lives", American Anthropologist 120 (4):738-751. https://doi.org/10.1111/aman.13126

Gunaratnam, Y. (2012) "Learning to be affected. Social suffering and total pain at life's borders", The Sociological Review 60 (S1):108-123. https://doi.org/10.1111/j.1467954x.2012.02119.x

Henriksson, B. (1995) Risk factor love. Homosexuality, sexual interaction and HIV prevention. Göteborg: Göteborgs universitet, Institutionen för socialt arbete.

Hochschild, A.R. (1979) "Emotion work, feeling rules, and social structure", American Journal of Sociology 85 (3):551-575. https://doi.org/10.1086/227049

Holland, J.M., C.P. Plant, L.K Klingspon \& R.A. Neimeyer (2020) "Bereavementrelated regrets and unfinished business with the deceased", Death Studies 44 (1):42-47. https://doi.org/10.1080/07481187.2018.1521106

Holmes, M. (2015) "Researching emotional reflexivity", Emotion Review 7 (1):61-66. https://doi.org/10.1177/1754073914544478

Hviid Jacobsen, M. (2010) "Tæt på døden”, Tidsskrift for Forskning i Sygdom og Samfund 7 (12):23-50. https://doi.org/10.7146/tfss.v7i12.2953

Hviid Jacobsen, M. (2016) "'Spectacular death'. Proposing a new fifth phase to Philippe Ariès's admirable history of death”, Humanities 5 (19):2-20. https://doi. org/10.3390/h5020019

Hviid Jacobsen, M. \& J. Brødslev Olsen (2014) ”Dødens socialpsykologi. Perspektiver på døden i samspillet mellem individ og samfund", Sosiologi i dag 44 (3):33-53.

Kauffman, J. (2002) "The psychology of disenfranchised grief. Liberation, shame, and self-disenfranchisement", 61-77 i K. Doka (red.) Disenfranchised grief. New directions, challenges, and strategies for practice. Champaign: Research Press.

Kavaliunas, A., P. Ocaya, J. Mumper, I. Lindfeldt \& M. Kyhlstedt (2020) "Swedish policy analysis for Covid-19", Health Policy and Technology 9 (4):598-612. https:// doi.org/10.1016/j.hlpt.2020.08.009

Kemper, T.D. (2006) "Power and status and the power-status theory of emotions", 87-113 i J.E. Stets \& J.H. Turner (red.) Handbook of the sociology of emotions. Boston: Springer. https://doi.org/10.1007/978-0-387-30715-2_5

Kleres, J. (2011) "Emotions and narrative analysis. A methodological approach", Journal for the theory of social behaviour 41 (2):182-202. https://doi.org/10.1111/ j.1468-5914.2010.00451.x

Kommittén om vård i livets slutskede (2001) Döden angår oss alla. Värdig vård vid livets slut. Slutbetänkande. SOU 2001:6. Stockholm: Fritzes offentliga publikationer.

Kulin, J., I. Johansson Sevä, M. Hjerm \& F. Fors Connolly (2021) "Oro över coronapandemin i det svenska samhället", Sociologisk Forskning 58 (1-2). https://doi. org/10.37062/sf.58.22104

Mas Giralt, R. (2019) "Bereavement from afar. Transnational grieving and the emotional geographies of migration", Children's Geographies 17 (5):578-590. https://doi. org/10.1080/14733285.2018.1447087 
McNutt, B. \& O. Yakushko (2013) "Disenfranchised grief among lesbian and gay bereaved individuals", Journal of LGBT Issues in Counseling 7 (1):87-116. https:// doi.org/10.1080/15538605.2013.758345

Morton, A. (2013) Emotion and imagination. Cambridge: Polity Press.

Osteruk, O. (2018) "Immigrants coping with transnational deaths and bereavement. The influence of migratory loss and anticipatory grief", Family Process 57 (4):10121028. https://doi.org/10.1111/famp.12336

Rosenfeld, D., B. Bartlam \& R.D. Smith (2012) "Out of the closet and into the trenches. Gay male baby boomers, aging, and HIV/AIDS", The Gerontologist 52 (2):255-264. https://doi.org/10.1093/geront/gnr138

Rostila, M., A. Cederström, M. Wallance, M. Brandén, B. Malmberg \& G. Andersson (2021) "Disparities in COVID-19 deaths by country of birth in Stockholm, Sweden. A total population based cohort study", American Journal of Epidemiology kwab057. https://doi.org/10.1093/aje/kwab057

SKR [Sveriges Kommuner och Regioner] (2020) "Fakta om äldreomsorgen. I ljuset av coronapandemin". https://skr.se/download/18.7c4d4e89178e9923 2a38699/1618921734063/Fakta_om_aldreomsorgen_i_ljuset_av_coronapandemin.pdf (hämtningsdatum 1 november 2020).

Socialstyrelsen (2013) Nationellt kunskapsstöd för god palliativ vård i livets slutskede. Vägledning, rekommendationer och indikatorer. Stöd för styrning och ledning. Stockholm: Socialstyrelsen.

Stolinski, A. M., C.S. Ryan, L.R.M. Hausmann \& M.A. Wernli (2004) "Empathy, guilt, volunteer experiences, and intentions to continue volunteering among buddy volunteers in an AIDS organization", Journal of Applied Biobehavioral Research 9 (1):1-22. https://doi.org/10.1111/j.1751-9861.2004.tb00089.x

Theodosius, C. (2006) "Recovering emotion from emotion management", Sociology 40 (5):893-910. https://doi.org/10.1177/0038038506067512

Van Bortel, T., A. Basnayake, F. Wurie, M. Jambai, A.S. Koroma, A.T. Muana, K. Hann, J. Eaton, S. Martin \& L.B. Nellums (2016) "Psychosocial effects of an Ebola outbreak at individual, community and international levels", Policy \& Practice 94 (3):210-214. https://doi.org/10.2471/blt.15.158543

Wettergren, Å., M. Holmes \& N. Manning (2020) "Emotions in the pandemic. Crisis and politics of change", Emotions and Society 2 (2):115-119. https://doi.org/10.133 2/263169020X15988069522042 


\section{Författarpresentationer}

Cathrin Wasshede är docent i sociologi vid Institutionen för sociologi och arbetsvetenskap, Göteborgs universitet. Med utgångspunkt i feministisk, queer och postkolonial teoribildning har Wasshede bedrivit forskning om motstånd, urbana sociala rörelser, barn och politiska gemenskaper. För närvarande medverkar hon i projektet "Slöja, regnbågsflagga och manga. Om genus, sexualitet, motstånd och gemenskap i en transnationell tid" (finansierat av Vetenskapsrådet).

Sofia Björk är lektor i sociologi vid Institutionen för sociologi och arbetsvetenskap, Göteborgs universitet. Björk har tidigare forskat om omsorgsrelationer i familjen och emotioners betydelse i relation till moraliska ideal och normer. För närvarande leder hon projektet "Föräldraförsäkringens betydelse för att forma en jämställd och rättvis vardag. En fråga om klass?" (finansierat av Forte).

\section{Kontaktuppgifter}

Cathrin Wasshede

Institutionen för sociologi och arbetsvetenskap Göteborgs universitet, Box 720, 40530 Göteborg

cathrin.wasshede@socav.gu.se 